\title{
IS IT IMPORTANT TO OVERCOME MOTOR PROBLEMS OF ELEMENTARY SCHOOL-AGE STUDENTS?
}

\author{
Citra Rahmawati ${ }^{1}$, Suhardi ${ }^{2}$ and Ali Mustadi ${ }^{3}$ \\ ${ }^{1}$ Primary Education, Postgraduates Program, Universitas Negeri Yogyakarta, Indonesia INDONESIA \\ ${ }^{2}$ Faculty of Languages and Arts, Universitas Negeri Yogyakarta, INDONESIA \\ ${ }^{3}$ Faculty of Education, Universitas Negeri Yogyakarta, INDONESIA
}

\section{SUMMARY}

The purpose of writing this article is to find out about the importance of overcoming motor problems of elementary school-aged students. The method used is a literature review study. Impaired motor development can cause learning difficulties. This will have an impact on students such as low scores, low achievement, and difficulties in learning. In addition to matters related to academics, students usually feel embarrassed or make other friends feel annoyed and uncomfortable. Seeing the impact caused by motor problems can interfere with the learning process of children, it requires intervention from the school, especially by teachers who interact more intensively with children. Motor problems experienced by elementary school students certainly require intervention, as an initial screening to find out problems that may be experienced by students, it is necessary to do a universal intervention. This universal intervention is an intervention given to students whose problems at first are not known. Four aspects can benefit from optimizing the development of children's motor skills. The four aspects are the child's physiological, emotional, cognitive, and social. Other benefits are also grouped based on the optimization of fine and gross motor skills. Recommendations for future research to examine more deeply the motor problems of elementary school-aged students, so that the right method can be found to overcome them.

Keywords: motoric, elementary school-age children, learning motion, child development 


\section{INTRODUCTION}

Development can be defined as a progressive and continuous change in an individual from birth to death (Hurlock, 2001; Phytanza, Burhaein, Sukoco, \& Ghautama, 2018). Development is not limited to the notion of growing growth, but also contains a series of changes that take place continuously and are permanent from the physical and spiritual functions of the individual to the stage of maturity through growth, maturation, and learning (Purnomo, Tomoliyus, \& Burhaein, 2019; Santrock, 2017). Development produces new forms and characteristics of abilities that go from a simple stage of activity to a higher stage. This development moves gradually but surely, through one form/stage to the next form/stage which is progressively progressing day by day, through the period of conception and ending in death (Dosil, Cremades, \& Rivera, 2014; Phytanza \& Burhaein, 2020). This shows that from the time of conception until death, the individual is never static, but always undergoes progressive and continuous changes.

Every normal individual will experience stages/phases of development. The developmental pattern period consists of five (5) stages (Santrock, 2017), namely: first, the prenatal period (conception to birth). Second, the neonates period (birth to 10-14 days). Third, infancy ( 2 weeks to 2 years). Fourth, childhood (2 years to adolescence). Fifth, puberty (11 to 16 years).

From a psychosocial perspective, it is argued that various periods in an individual's life require the completion of specific developmental tasks. Developmental tasks are further divided into several stages, namely developmental tasks at infancy or childhood (ages 0-6 years), developmental tasks at school (6-12 years), and developmental tasks in adolescence (Santrock, 2017).

Developmental tasks at infancy are as follows (Hurlock, 2001; Pramantik \& Burhaein, 2019): first, learning to walk occurs between 9-15 months of age. Second, learn to eat solid foods, which is what happens in the second year. Third, learn to speak. Fourth, learn to urinate and defecate. Fifth, learn to recognize gender differences. Sixth, achieve physiological stability. The seven form a simple concept of social and natural reality. Eighth, learning to relate emotionally with parents, siblings, and other people. Ninth, learn to distinguish right from wrong and develop a conscience.

Developmental tasks during the school period are as follows (Burhaein, 2017a; Phytanza \& Burhaein, 2019): first, learn the physical skills needed for children's play. Second, build a holistic attitude towards oneself as a growing organism. Third, learn to get along with peers. Fourth, learn to play gender-appropriate roles. Fifth, learn basic skills in reading, writing, and counting. Sixth, learn to develop everyday concepts. Seventh, learn to develop a conscience. Eighth, learn 
to achieve personal independence. Ninth, forming attitudes towards social groups and institutions.

Motor development is one of the aspects of development in children and is a very important factor for overall personal development (Burhaein, 2017b; Burhaein, Phytanza, \& Demirci, 2020). If the child has problems in motor development, the child will experience difficulties in carrying out daily activities both at school and at home. Early childhood has a natural need to move and reflex, since birth, children are created to be able to move their motor. For example, when the child is born naturally, the child will move his feet and hands. This natural talent then becomes a window for children to build their knowledge. This potential is an asset to develop children's skills in physical exercise.

Motor skills in children consist of gross motor skills and fine motor skills (Breslin, Morton, \& Rudisill, 2007; Burhaein, Ibrahim, \& Pavlovic, 2020). Motor skills of children aged 4-5 years are more developed in gross motor skills, after the age of 5 years, fine motor development occurs. Motor development is specific, each individual has different movements from other individuals, this is influenced by cognitive abilities, affective abilities, environmental factors, and biological factors of the individual concerned. Motor development is a development that requires good functional coordination between the neuromuscular system, namely nerves and muscles with psychic functions which include cognitive, affective, and conative. From the explanation above, gross motor skills in the form of muscles and nerves are interconnected with fine motor skills in the form of psychological aspects. So it can be ascertained that children's motor development will develop well when gross and fine motor skills coordinate well with each other (Moser, Reikerås, \& Tønnessen, 2017).

Motor problems that tend to be experienced by children, usually occur in terms of controlling their body movements, for example, students often fall or hit something when walking, difficulty distinguishing left and right, difficulty making simple movements such as jumping, going up and downstairs, difficulty distinguishing sounds and so on (Kashfi, Sohrabi, Kakhki, Mashhadi, \& Nooghabi, 2019). These various motor development disorders are often easily recognized when the child is exercising, dancing or learning to write. Impaired motor development can cause learning difficulties. This will have an impact on students such as low scores, low achievement, and difficulties in learning. In addition to matters related to academics, students usually feel embarrassed or make other friends feel annoyed and uncomfortable. 


\section{MOTORIC DEVELOPMENT OF ELEMENTARY SCHOOL-AGE CHILDREN}

Motor development develops in line with the maturity of the nerves and muscles of the child (Burhaein, 2020a, 2020b). Thus, every movement no matter how simple it is the result of a complex interaction pattern of various parts and systems in the body controlled by the brain. However, the development of gross motoric and fine motor skills in each child is different (Mustofa, Mansur, \& Burhaein, 2019). So there are age benchmarks regarding what abilities a child needs to achieve at a certain age. The existence of this benchmark is intended so that children who have not reached this certain level of ability need to be trained in various abilities to be able to achieve optimal development.

Table 1. Gross and Fine Motor Development Ages 6 - 8 years

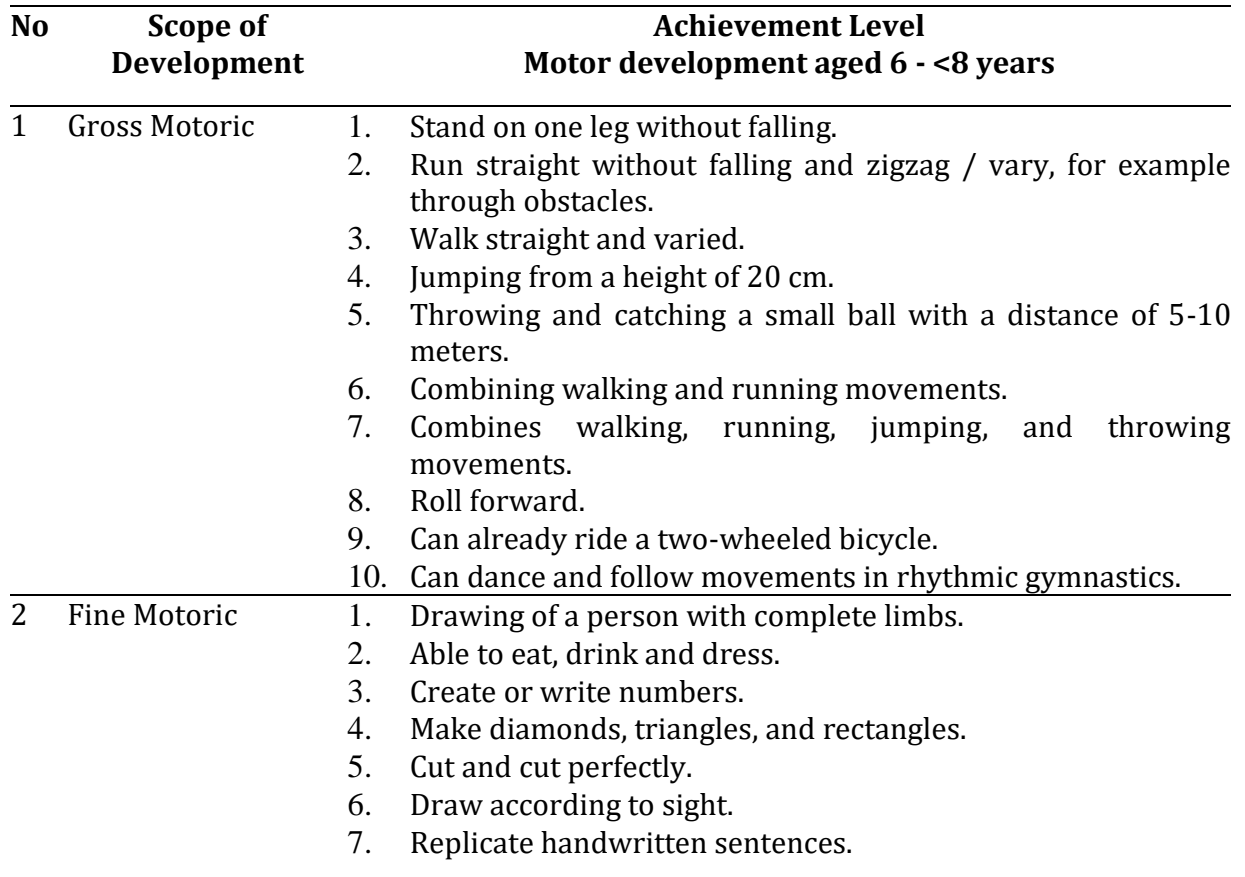

Source: (Burhaein, 2017a; Hurlock, 2001; Santrock, 2017)

At elementary school-age, children's motor development becomes more refined and coordinated, along with the child's weight gain and strength. From the age of 6 years, eye and hand coordination (which is required for kicking, aiming, throwing) are more developed. At the age of 7, the child's hands are getting stronger. From 8 to 10 years old, hands can be used more freely and easily. At 10 
to 12 years of age, children begin to exhibit manipulative skills similar to those of adults (Burhaein, 2017a; Hurlock, 2001; Santrock, 2017). They began to show movements that were more complex, complicated, and fast in terms of creating certain crafts or playing certain musical instruments.

\section{MOTOR PROBLEMS OF ELEMENTARY SCHOOL-AGE CHILDREN}

The perceptual-motor is a perceptual process combined with a process of muscle or motor movement. In other words, it can be interpreted that the perceptual motor is the ability to control body movements. Difficulty in motor perception inhibits children's development because children do not master perceptual-motor skills, namely skills in gross motor coordination and fine motor coordination to complete various tasks related to the combination of visual movement and motor movement. For example in integrating eyes and hands when writing, painting, buttoning clothes, coordination between feet and eyes when playing ball, kicking a ball, playing jumping rope (Breslin et al., 2007; Burhaein, 2017a).

Motor perception difficulties are difficulties in processing the information received by the senses motorically. Children who experience motor problems will experience some difficulties, for example, they cannot understand words or visual symbols, cannot understand the right, left, up, and down positions, and cannot understand movements and determine movements that are appropriate to solving the problems they face.

Seeing the impact caused by motor problems can interfere with the learning process of children, it is necessary to take an intervention from the school, especially by teachers who interact more intensively with children. There are four classifications of intervention based on the severity of the problem, namely (1) Universal Intervention, an intervention given to the general population that has not shown a problem, (2) Targeted Intervention, intervention in a population at risk of experiencing problems, (3) Intensive Intervention, intervention in a population where some individuals have experienced problems, and (4) Crisis Intervention, an intervention given to a problematic population. As an initial screening to find out motor problems that might be experienced by students, a universal intervention was carried out.

\section{FACTORS THAT INFLUENCE CHILDREN'S MOTOR DEVELOPMENT}

Several conditions affect the rate of motor development, among others (Breslin et al., 2007; Burhaein, 2017a): First, genetic characteristics, including body shape and intelligence, have a prominent influence on the rate of motor development. 
Second, in early postnatal life, there are no obstacles to unfavorable environmental conditions, the more active the fetus is, the faster the motor development of the child is. Third, pleasant prenatal conditions (mother's dietary nutrition) encourage more rapid motor development in the postpartum period. Fourth, difficult birth, if there is damage to the brain will slow down motor development. Fifth, the presence of stimulation, encouragement, and the opportunity to move all parts of the body will accelerate motor development. The sixth factor, excessive protection will cripple the preparation for the development of motor skills. Seventh, premature birth usually slows motor development. Eighth, physical disabilities, such as blindness will slow down motor development. And lastly, differences in gender, skin color, and socio-economy are more caused by differences in children's motivation and training methods than due to innate differences.

Furthermore, there are eight (8) factors that influence motor development (Burhaein, 2017a; Santrock, 2017), including the first factor, the development of the nervous system, the nervous system is very influential in motor development because basically, the nervous system controls motor activity in humans. Second, physical conditions greatly affect motor development. A normal person usually has better motor development than those who have physical disabilities. Third, strong motivation when someone performs motor skills well, it is likely that someone will be motivated to master broader and higher motor skills. Fourth, a conducive environment is likely to support a person's motor development so that they can run optimally. The environment here can mean facilities, equipment, facilities, and infrastructure. Fifth, the psychological aspect, only someone with a good psychological condition can achieve good motor skills. Despite having a supportive physical condition, a person's psychological condition is not good, it is difficult for that person to achieve optimal and satisfying motor skills. Then, the sixth factor that affects motor development is age, which is very influential on a person's motor activity. Babies, children, adolescents, adults, and the elderly certainly have different characteristics of motor skills. Seventh, gender, especially in certain motor skills, for example, sports (swimming, badminton, volleyball, tennis, football), a man is certainly stronger, faster, skilled, and agile than women. Eighth, talents and potentials also influence efforts to achieve motor skills. For example, someone can easily be directed to become a reliable footballer if he has talent and potential as a footballer.

Based on the description above, the age of each individual is very influential on motor development. The higher the age of a person, the more mature the physiological organs. However, this maturity cannot be separated from the nutrients, nutrients, vitamins that are obtained every day, so that the strength of the head, hands, and feet can develop perfectly. 


\section{BENEFITS OF OPTIMIZING CHILDREN'S MOTOR DEVELOPMENT}

Children's motor skills have various benefits. Not just for walking or holding, motor skills are also beneficial for the development of the child as a whole. Four aspects benefit from the development of children's motor skills. The four aspects are the child's physiological, emotional, cognitive, and social (Burhaein, 2017a; Burhaein, Tarigan, \& Phytanza, 2020; McLaren, 2010; Santrock, 2017).

1. Physiological aspects, great motor skills will make him move and exercise more. This makes blood circulation, breathing, and body posture better. Gross motoric activities of children are the beginning of children getting to know sports and physical activities. If a child is used to physical exercise/sports from a young age, it will have good results.

2. Emotional aspects, children with good motor skills will have great selfconfidence. This makes him more accepted in his environment so that it is also directly beneficial to the social aspect.

3. The social aspect has a correlates with the emotional aspect. Children will be more easily accepted if they have good motor skills and better movement.

4. The cognitive aspect is one of the benefits of good motor skills. Good motor skills will benefit the child's brain (cognition) and mental development. The existence of children's motor skills will also foster children's creativity and imagination which are part of children's mental development. Thus, experts often emphasize that physical activity and sports will improve children's intellectual abilities.

The benefits of developing children's motor skills in more detail are divided into fine and gross motor skills (Burhaein, 2017a; McLaren, 2010; Zieff, Lumpkin, Guedes, \& Eguaoje, 2009), as follows:

1. The benefits of developing fine motor skills are related to 1) How children systematically process their thoughts according to their age. It is integrated into the game, putting together puzzles, arranging toys, being patient building blocks, printing shapes with sand; 2) Ability "life skills", such as holding a spoon, eating alone, removing and wearing own socks and shoes, closing doors without slamming, stirring drinks and pouring drinks; 3) Activities with simple instructions. The problem is that children in school can hold scissors, cut according to instructions, color patiently, rattle small objects, fold folded paper according to simple instructions, hold crayons and markers, thickly dotted lines, and complete simple instructions well. 
2. The benefits of developing gross motor skills are related to 1) Overall physical exercise, walking on a well-balanced beam, playing ball, jogging, playing obstacle courses in outdoor playgrounds in general, such as "spider web", climbing tunnels, and climbing balance ladders. ; 2) Simple life skills of children, such as being able to ride a bicycle with an assistive wheel and gradual according to their age; 3) Preschool, such as playing ball by throwing and catching, kicking, jumping on or onto objects, social coordination with friends and cooperation.

\section{CONCLUSION}

Motor development is the development of the elements of maturity and controlling body movements. Motor development in children develops in line with the maturity of nerves and muscles. If there are no physical disorders and mental barriers that interfere with motor development, children aged 6 years will normally be ready to adapt to school demands and participate in peer-to-peer play activities. The most important child development tasks in the preschool and early school years consist of motor development. In this case, motor development in children is one thing that needs to be considered because this is important so that children can control their body movements.

Motor problems that tend to be experienced by children, both at home and at school in terms of controlling their body movements, for example, students often fall or hit something when walking, difficulty distinguishing left and right, difficulty making simple movements such as jumping, going up and downstairs, difficulty distinguishing sounds and so on. These various motor development disorders are often easily recognized when the child is exercising, dancing, or learning to write. Impaired motor development can cause learning difficulties. This will have an impact on students such as low scores, low achievement, and difficulties in learning. In addition to matters related to academics, students usually feel embarrassed or make other friends feel annoyed and uncomfortable.

Seeing the impact caused by motor problems can interfere with the learning process of children, it requires intervention from the school, especially by teachers who interact more intensively with children. Motor problems experienced by elementary school students certainly require intervention, as an initial screening to find out problems that may be experienced by students, it is necessary to do a universal intervention. This universal intervention is an intervention given to students whose problems at first are not known.

Four aspects benefit from the development of children's motor skills. The four aspects are the child's physiological, emotional, cognitive, and social. Other benefits are also grouped based on fine and gross motor skills. Recommendations 
for future research to examine more deeply the motor problems of elementary school-aged students, so that the right method can be found to overcome them.

\section{Conflict of Interest}

The author states there is no conflict of interests.

\section{REFERENCES}

1. Breslin, C. M., Morton, J. R., \& Rudisill, M. E. (2007). Implementing a Physical Activity Curriculum into the School Day : Helping Early Childhood Teachers Meet the Challenge. Early Childhood Education Journal, 35(1), 429-437. https://doi.org/10.1007/s10643-007-0200-9

2. Burhaein, E. (2017a). Aktivitas Fisik Olahraga untuk Pertumbuhan dan Perkembangan Siswa SD. Indonesian Journal of Primary Education, 1(1), 51-58. https://doi.org/10.17509/ijpe.v1i1.7497

3. Burhaein, E. (2017b). Aktivitas Permainan Tradisional Berbasis Neurosainslearning Sebagai Pendidikan Karakter Bagi Anak Tunalaras. Jurnal SPORTIF : Jurnal Penelitian Pembelajaran, 3(1), 55. https://doi.org/10.29407/js_unpgri.v3i1.580

4. Burhaein, E. (2020a). Bagaimana Pendidikan Jasmani Adaptif di Era New Normal. In Bunga Rampai Strategi, Proses, Evaluasi, dan Model Pembelajaran Pendidikan Jasmani, Olahraga, dan Kesehatan (PJOK) pada Era Pandemi Covid-19. Surabaya: UNESA University Press.

5. Burhaein, E. (2020b). Pembelajaran dalam Pandemi COVID-19: Mengapa Pendidikan Jasmani Adaptif Penting untuk Siswa Disabilitas di Sekolah Luar Biasa. In Disrupsi Strategi Pembelajaran Olahraga: Serta Tantangan dalam Menghadapi New Normal selama masapandemi Covid-19 (pp. 187-196). Tulungagung: Akademia Pustaka.

6. Burhaein, E., Ibrahim, B. K., \& Pavlovic, R. (2020). The Relationship of Limb Muscle Power, Balance, and Coordination with Instep Shooting Ability : A Correlation Study in Under-18 Football Athletes. International Journal of Human Movement and Sports Sciences, 8(5), 265-270. https://doi.org/10.13189/saj.2020.080515

7. Burhaein, E., Phytanza, D. T. P., \& Demirci, N. (2020). The development and validation of a revised Friendship Activity Scale and Adjective Checklist for use in the Indonesian Unified Sports program. International Sports Studies, 42(e), 1828. https://doi.org/10.30819/iss.42-e.03

8. Burhaein, E., Tarigan, B., \& Phytanza, D. T. P. (2020). The experience and understanding of the K-13 curriculum implementation of Indonesian teachers of Adapted Physical Education (APE). International Sports Studies, 42(e), 29-42. https://doi.org/10.30819/iss.42-e.04

9. Dosil, J., Cremades, J. G., \& Rivera, S. (2014). Psychological skills training and programs. In Routledge companion to sport and exercise psychology: Global perspectives and fundamental concepts. 
10. Hurlock, E. B. (2001). Developmental psychology. New York: McGraw-Hill Education.

11. Kashfi, T. E., Sohrabi, M., Kakhki, A. S., Mashhadi, A., \& Nooghabi, M. J. (2019). Effects of a Motor Intervention Program on Motor Skills and Executive Functions in Children With Learning Disabilities. Perceptual and Motor Skills, 126(2), 477498. https://doi.org/10.1177/0031512519836811

12. McLaren, H. (2010). Physical Education and Physical Activity: Opportunities for Students with a Disability. South Australia: Govenrment of South Australia.

13. Moser, T., Reikerås, E., \& Tønnessen, F. E. (2017). Development of motor-lifeskills : variations in children at risk for motor difficulties from the toddler age to preschool age. European Journal of Special Needs Education, 6257(May), 0. https://doi.org/10.1080/08856257.2017.1306964

14. Mustofa, F., Mansur, M., \& Burhaein, E. (2019). Differences in the effect of learning methods massed practice throwing and distributed distributed practice on learning outcomes skills for the accuracy of top softball. Journal of Sport Sciences Researches, 4(2), 213-222. https://doi.org/10.25307/jssr.571793

15. Phytanza, D. T. P., \& Burhaein, E. (2019). Aquatic activities as play therapy children autism spectrum disorder. International Journal of Disabilities Sports and Health Sciences, 2(2), 64-71. https://doi.org/10.33438/ijdshs.652086

16. Phytanza, D. T. P., \& Burhaein, E. (2020). The Effects of Tenure, Teacher Certification, and Work Motivation on Special Needs Teacher Performance. Universal Journal of Educational Research, 8(9), 4348-4356. https://doi.org/10.13189/ujer.2020.080962

17. Phytanza, D. T. P., Burhaein, E., Sukoco, S., \& Ghautama, S. W. (2018). Life Skill Dimension based on Unified Sports Soccer Program in Physical Education of Intellectual Disability. Yaşam Becerileri Psikoloji Dergisi, 2(4), 199-205. https://doi.org/https://doi.org/10.31461/ybpd.453865

18. Pramantik, I. A. D., \& Burhaein, E. (2019). Disabilities Sports \& Health Science A Floor Time Approach to Improve Learning Outcomes of the Body Roll to the Side in Adaptive Physical Education Learning : Classroom Action Research Study on Two Cerebral Palsy Students. International Journal of Disabilities Sports and Health Sciences, 2(2), 45-53. https://doi.org/10.33438/ijdshs.652061

19. Purnomo, I. D., Tomoliyus, T., \& Burhaein, E. (2019). Development of Learning Activities Playing a Ball on a Goal To Improve Manipulative Skills For Lower Class Students. Proceedings of the 1st International Conference on Science and Technology for an Internet of Things. https://doi.org/10.4108/eai.19-102018.2281716

20. Santrock, J. W. (2017). Educational psychology (6th ed.). New York: McGraw-Hill Education.

21. Zieff, S. G., Lumpkin, A., Guedes, C., \& Eguaoje, T. (2009). NASPE Sets the Standard. Journal of Physical Education, Recreation \& Dance, 80(8), 46-49. https://doi.org/10.1080/07303084.2009.10598378 


\title{
ВАЖНО ЛИ ПРЕОДОЛЕВАТЬ ДВИГАТЕЛЬНЫЕ ПРОБЛЕМЫ УЧАЩИХСЯ МЛАДШЕГО ШКОЛЬНОГО BO3РАCTA?
}

\begin{abstract}
АННОТАЦИЯ
Цель написания статьи - выяснить важность решения проблем двигательной активности учащихся младшего школьного возраста. Используемый метод представляет собой обзорное исследование литературы. Нарушение двигательного развития может вызвать трудности в обучении. Это может повлиять на студентов в плане низких баллов, слабых достижений и трудностей в обучении. В дополнение к академическим вопросам стоит отметить, что студенты обычно чувствуют себя неловко или заставляют других друзей чувствовать себя раздраженными и не вполне комфортно. Понимая, что двигательные проблемы могут помешать процессу обучения детей, требуется вмешательства со стороны школы, особенно учителей, которые более тесно взаимодействуют с детьми. Проблемы двигательные, которые испытывают учащиеся начальной школы, безусловно, требуют вмешательства, и в качестве первоначального скрининга для выявления проблем необходимо предпринять универсальные меры. Такие универсальные меры предназначены для студентов, чьи проблемы неизвестны с самого начала. Четыре аспекта могут принести пользу от оптимизации развития двигательных навыков детей - физиологические, эмоциональные, когнитивные и социальные. Другие преимущества также сгруппированы на основе оптимизации мелкой и крупной моторики. Рекомендуется в будущих исследованиях более глубоко изучить двигательные проблемы учащихся младшего школьного возраста, чтобы найти правильный метод их преодоления.
\end{abstract}

Ключевые слова: моторика, дети младшего школьного возраста, обучающее движение, развитие ребенка

Reccived on 22.03.2021.

Accepted on 09.05.2021. 